\title{
10
}

\section{PRME CHAPTER CENTRAL \& EASTERN EUROPE}

\author{
Mikolaj Pindelski
}

\subsection{Purpose of PRME CEE Chapter}

The research on CSR, ethics, and sustainability conducted among business professionals, academics, and university representatives shows up its importance in corporate and employees' personal life. Engagement in CSR is related to stakeholders' attitudes and the favorable relationship between them and companies, supportive customer behaviors, and corporate image. All that may result in supportive behaviors in case of corporate image failures or brand problems. The sought results are negatively correlated to the low awareness of CSR activities (Du, Bhattacharya, Sen, 2010). That may mean that CSR attitudes and activities are being appreciated by stakeholders what makes it reasonable to implement socially responsible goals into the company's strategy and influence organization members' appropriate attitudes. That makes it reasonable to shape socially responsible leaders on the level of university education. In particular in the CEE countries where the discussion over the need of social attitude of organizations is relatively new (Remisova, Lasakova, 2014; Fijałkowska, Zyznarska Dworczak, Garsztka, 
2017). That is presented in the CSR activities reported by the main CEE market players in the environmental influence context (Mrowka, Pindelski, 2012). Companies, or in broader sense organizations, consider their economic goals in the relation to the social needs (Pindelski, 2012). That refers to the critical need for CSR activities and their effective communication to stakeholders to achieve business results and benefits. In this context, the idea and conceptual framework of the educational intentions were created in CEE countries. That called to live the CEE Chapter and built up its assumptions and basements.

CSR and business ethics increase in importance in management and economy education. Numerous universities, business schools, and other educational institutions add these topics to the curricula. Based on the 6 PRME Principles and 17 United Nations Sustainable Goals are being welcome by students. However, the process of its implementation still requires some improvements what is also the case of the Central and East European regions. In this regard, the PRME CEE Steering Committee has launched, just triggered, or supported several activities in both teaching and research activities. The integration of ethics, sustainability, and social responsibility in the research and educational programs is also aimed at public, regulatory, and other organizations in the region. Since the CEE Chapter's existence beginning the focus was set on the popularization of the idea, teaching programs, and research results. There were undertaken efforts to establish a pool of specialists to shape a think-tank in the region on the social issues in the field of academia and the next steps overall. It is to support local leaders, educational, business, and governmental institutions. That broaden Chapter activities on the area of promoting results of the research, teaching, and social efforts of all the PRME CEE members and their representatives.

\subsubsection{History and membership of Chapter}

The PRME CEE Chapter was founded in 2016 during the Conference at Riseba University in Riga, Latvia. Since its beginning, the main direction is to give a strong voice to PRME signatories of the CEE region within the PRME initiative on the responsible and sustainable management education concept. It is as well to promote the ideas of CSR, sustainability, and simply ethical and decent behavior among universities, schools, and 
other educational institutions in the CEE region. In particular that works toward the efforts to make the CSR and related concepts significant for the authorities and secure them an important place in the educational programs' portfolio. The exchange of ideas, highlighting best practices, and create a platform for the proliferation of the PRME Principles.

The idea to implement the CSR issues that root from the UN basics into the university curricula is of high importance in the region. Countries represented in the CEE Chapter have in common a post-communism history and the issues described in the PRME six principles are relatively new according to the curricula and attitudes of the societies. The specific approach represented in the CEE region requires more local and locally oriented initiatives. It is the CEE Chapter that has been established for. We assume that it is the only way to work toward the six principles implementation in the educational entities in the region.

During the 2016-2020 period, the PRME CEE Chapter has been represented by the board representing several schools and universities. The board has been reshaped several times and the list of the representatives also changed. The representatives involved in the board during that time are listed below.

- Irina Sennikova from the Riseba University, Riga, Latvia.

- Evgenia Paskevitch from the Ranepa Russian Presidential Academy, Moscow, Russia.

- Dusan Kucera, University of Economics Prague, Prague, Czech Republic.

- Gabor Harangozo, Corvinus University, Corvinus Business School, Budapest, Hungary.

- Mikolaj Pindelski, Warsaw School of Economics, SGH, Warsaw, Poland.

- Svitlana Kyrylchuk, Lviv Business School of Ukrainian Catholic University, Lviv, Ukraine.

- Olga Veligurska, CEEMAN Management development Association, Ljubljana, Slovenia.

- Assylbek Kozakhmetov, Almaty Management University, Almaty, Kazakstan.

- Nina Koryakina, Lomonosov Moscow State University, Moscow, Russia.

- Judita Peterlin, University of Ljubljana School of Economics and Business, Ljubljana, Slovenia. 
Since that moment now our network rose and get reshaped. More Universities joined PRME and the PRME CEE Chapter. Lomonosov University in Moscow Russia, Kraków University of Economics Poland, Kozminsky University Poland, University of Ljubljana School of Economics and Business, and many others. As for the mid of 2020, we gather 59 PRME signatories from the region. Poland (11), Russia (11), Latvia (8), Czech Republic (6), Kazakhstan (3), Lithuania (3), Croatia (3), Slovenia (2), Hungary (2), Ukraine (2), Bulgaria (2), Slovakia (1), Estonia (1), Belarus (1), Romania (1), Albania (1), Macedonia (1). There are still countries from the region that are not represented as Moldova, Montenegro, Serbia, Bosna \& Herzegovina, Kosovo. It is the goal to attract the educational institutions from these countries to the PRME network and work together for better implementation of the six principles.

\subsection{Deliverable of the Chapter}

From CSR to SCR (Sustainable Corporate Responsibility) - guide and teaching programs created by PRME CEE Chapter

As one of the initial steps of its activity, the PRME CEE has developed teaching programs on social issues to be implemented in the academic curricula.

The program was tested by the PRME CEE Steering Committee members during internal training. As a result, we delivered a material, agenda, recommendations, and requirements enriched by best practices. Starting to talk on the proposed course back to the initial meeting in Riseba, Riga Latvia 2016, the shape was set during the meeting in Ranepa, Moscow Russia as an event during the Gaidar Forum 2017. Those days were also placed the PRME CEE Chapter meeting. The final results were delivered during the Conference and meeting at the University of Economics in Prague, Czech Republic. As the final version agreed applications for universities. The entire program is formulated around the PRME 6 Principles: Purpose, Values, Method, Research, Partnership, Dialogue. The course(s) are not limited in hours count but is a flexible form ranging from few to few dozens of teaching hours depending on the local context and possibilities. It was also recommended to PRME signatories to implement the course or at least consider its implementation in the curricula in the nearest future. As most of the universities have had already started their courses in the 
discussed field, the presented description dealt as a supplement, best practice, or trigger for refreshing the topics and the ways these are being taught.

The teaching program assumed that from the class discussions on business ethics it is possible to come up with ethical professional behaviors. The course is related to CSR (Corporate Social Responsibility) and SCR (Sustainable Corporate Responsibility). In particular, the course is aimed at attitudes to CSR and the next step - deeper and more advanced SCR concept. That comes out from the conclusion that there is no universal ethics one can learn. It is more on asking her or himself a question of whether a managerial decision may or may not create harm to others and for what cost are being achieved economical goals. Implantation of such doubt or a habit became the main idea of the course.

As the initial step of the program, we suggest the pre-class test on ethical and social issues. The test consists of short case studies presenting some ethical issues. Short cases to be evaluated, whether organizational behaviors presented were sustainable, ethical, or socially responsible. Students are being asked to present their reactions and possible decisions regarding their attitude to CSR as well as their general knowledge on that topic. That is also to collect a pool of possible problems for further discussions during ongoing classes and to provoke the discussion concerning students' answers.

After the test, some fundamentals of management are raised. This part of the course consists of deep philosophical questions on ethics and responsibility concerning business goals and activities. Example: "What does it mean to manage ethically?" or "Why do some companies perform responsible socially and some do not?" The questions are supported by live examples of responsible and irresponsible organizational behaviors to some stakeholders.

As an example problem to be discussed with students is, "How the problem of an autonomous car should be solved?" There is a description of the company producing or designing an autonomous car and facing a problem of the algorithm describing the possible situation a car may get into. The autonomous car is on the two way street in two directions. Along the street, there is a raw of big trees. Suddenly a group of pedestrians is entering the street in a way that does not allow the car to brake and stop, and harmlessly solve the situation. The only possible solution is to crash the car or hit pedestrians. The possible decisions are:

- $\quad$ Always save passengers at any cost.

- $\quad$ Always save pedestrians at any cost. 
- Hit the tree along the street and save pedestrians (but what with customers who are not always protected and a possible drop in company income?).

- Save passengers and hit pedestrians (but what with social responsibility?).

- Hit a car on the other line coming from the opposite direction.

- The car should evaluate who is in the car and who on the street and calculate the value of the passengers vs. the value of pedestrians and make the decision based on the valuation,

- The car should decide by itself based on statistical calculations which decision will cause less harm.

- The car should make random decisions by itself.

- Other solutions.

The discussion should lead to some conclusions showing the problems with defining ethics, CSR, or sustainability on the organizational level. It should also conclude with findings on what does it mean that organizations act responsibly and what influences that behavior. As a result, students can ask themselves questions and evaluate the results of their managerial decisions that may affect stakeholders. This is to make first students, future leaders act and think ethically, sustainable, socially responsible but at the same time able to evaluate whether the business and organizational behaviors are sustainable, ethical, and socially responsible.

After the first part of the course, it is recommended to use short case studies and discuss with students ethical issues on business goals and the social role of an organization in particular business-oriented. It is to:

- Make students answer questions and ask questions themselves.

- Direct students thinking instead of delivering them the knowledge only.

Getting deeper into the topic, arises the question, "What is CSR and what SCR?” To explain the difference, a teacher should ask students for examples of socially responsible and socially irresponsible actions on each of the levels listed below:

- Event

- Product

- Strategy 
- Operations

- Organizational culture

- Business model

- Human behavior

- $\quad$ Other, please specify

After discussion, the answers should be listed and related to the previous conclusions explaining what are the differences between CSR and SCR concepts.

Next class or even classes are devoted to irresponsible organizational behaviors. The case studies and discussions should lead to describe context and situations when a company acts unethically or socially irresponsible. An important follow-up is finding answers to the question, "How should one react to visibly irresponsible organizational behavior?" The answers may not be clear or cannot lead to an unambiguous conclusion. This is also to be explained and discussed as sustainability, ethics, or social responsibility depend on numerous variables. Among international students differences in opinions may result from national cultures they represent (Cuerel Burbano, Hawn, 2018), local context (McDonagh et al., 2020), and according to corporate sustainability performance may depend on several factors (Lee et al., 2009) with the link to competitive advantages (Porter, Kramer, 2006). That would be also worth discussing the influence of corporate sustainability on financial results, as the research show very different results from not enhancing the financial performance (Mittal et al., 2008; Lanoizelee, 2011; Atriach et al., 2010), over partly enhancing (Laan et al., 2008; Andersen, Larsen, 2009; Gupta, 2012) to enhancing corporate financial performance (Clemens, Bakstran, 2010; Menguc et al., 2010; Rahim et al., 2011).

An important issue remains here also trends and consumers who tend to value sustainable policies and behaviors of suppliers (Cordasco, 2012; Stanisavljevic, 2017). What expresses in their purchasing decisions, loyalty, and brand evangelism (Panda et al., 2020).

After completing the classes there should be conducted a post-class test constructed of short case studies presenting social and sustainability issues to ask students to evaluate, whether organizational behaviors were sustainable, ethical, and socially responsible. The post-class test is more to evaluate the changes in students' attitudes to the taught issues (progress would not be the right word here) than to value test results. After the post-class test, 
there is still room to further discuss the results and changes in attitudes since the pre-class test results. The students should be asked to find out differences in their approach. It is to make them aware that thinking on ethics and social responsibility are needed in every place of a company.

As the summary and course wrap up students should be asked to describe the ways on how to deal with CSR and SCR challenges in organizations. As a result of making students ask themselves ethical questions and looking for answers the course summary is to define:

- CSR as a situation when companies help societies and solve social problems.

- SCR as CSR deeply embedded into the company's DNA and is visible in every decision made by a company. It prefers big social goals even if it causes a slowdown of a company's growth.

Based on this program assumptions several internal pieces of training have been led by the Chapter Steering Committee members mostly in their mother institutions. Training organized within the framework of the PRME CEE Chapter opens up new perspectives on corporate ethical responsibility to professors, politicians, educators, management trainers, and leaders, both in business and society.

\subsection{Research activities}

In relevance to words by António Guterres, United Nations secretarygeneral, "The PRME initiative was launched to nurture responsible leaders of the future. Never has this task been more important. Bold leadership and innovative thinking are needed to achieve the Sustainable Development Goals." That motivated the PRME CEE Chapter to launch research activities. As PRME (Principles for Responsible Management Education) has the word "education" in its name, it is aimed mainly at higher education institutions. PRME CEE Chapter members have come to the conclusion that education at this level is not possible without research and contemporary discoveries and insights.

Two research projects are being in the run and launched by PRME CEE Chapter. First is exploring the dependence and correlation between the psychological portrait of students and their perception of PRME six principles adoption in Central and Eastern European educational institutions. 
The research uses qualitative methods and tools. The research problem on PRME Principles adoption has been announced by numerous authors (Hillon, 2017; Haertle, Miura, 2014). There were also researched values of students of PRME signatories concerning cross-cultural differences (Haski-Leventhal, 2014). There were named barriers in PRME principles implementation at universities according to their genesis. The search for the obstacles have been conducted on a systemic level (Allen et al., 2019), organizational level (Reficco et al., 2019), small units and group dynamics level (Silvius, Schipper, 2018), or on a single actor level (Hogdal et al., 2019). PVQ uses an existing tool of Portrait Values Questionnaire that differ from IRVS (Individual Reflexive Value Scale) and SVS (Schwartz Values Scale) though may lead to similar results (Shmidt et al., 2007). We used the PVQ, as that tool tries to portray respondents in terms of their values and aspirations in more concrete and context-based ways than SVS. The SVS stimuli are context-free values (Schwartz et al., 2001).

The results of the PVQ questionnaire are put together with the results on questions on perception of PRME Six principles implementation and its impact on education and shaping future leaders. The research is being conducted and promoted among students of CEE countries universities.

The second research is based on qualitative research and consists of case studies presenting best and worst practices in PRME six principles implementation in educational institutions in particular into their curricula and life. The research project is to collect insights and experiences of development and way of thinking on how to make work the idea of new, sustainable leaders shaping based on PRME principles and teaching programs. The case study method is to define the ideas, problems, and more detailed issues to research in the future. Further research will be to improve the ways the PRME principles are being called to life at universities and other educational institutions, PRME signatories.

\subsection{Recent activities}

\subsubsection{PRME session during 28th Ceeman Annual Conference, online, 26September 2020}

During this online session Prof. Mette Morsing, Prof. Danica Purg, and Prof. Mikolaj Pindelski gave a sound voice to PRME CEE chapter challenges related to regional needs. 


\subsubsection{First Online Chapter Talks, 16 September 2020}

Opened by Prof. Mette Morsing (PRME), Prof. Jacek Prokop (SGH), Prof. Assylbek Kozakhmetov (Almaty Management University). Then Mikolaj Pindelski (SGH) opened the session. The speech was given by Prof. Evgenia Paskevitch (Ranepa University, Moscow) on "Political events and COVID situation - how the recent situation affects our activities as educational institutions, how we can help students not to get confused in the turmoil and ensure that they maintain their integrity and develop into responsible leaders for sustainable post-pandemic world." Then we discussed the issues called by Prof. Paskevitch. As a special guest was invited Vanessa Moutinho, a social entrepreneur from Rio de Janeiro, Brazil who presented us the social perspective of social entrepreneurs and discussed "How to remain decent in turbulent times."

\subsubsection{Seventh PRME CEE Regional Meeting, online, PRME zoom platform, 4 June 2020}

Welcome words were provided by Prof. Danica Purg, former head of PRME; Prof. Mette Morsing, PRME head; Prof. Jacek Prokop, vice-rector for Int'l Affairs of SGH; and Mikolaj Pindelski, PRME CEE. The was launched session on research with presentations and discussions). The speeches were given by Reka Matolay, PhD, Corvinus University, and Dusan Kucera, $\mathrm{PhD}$, Mikolaj Pindelski, Prof. PhD hab., on PRME versus PVQ values and online research among students. The next session was devoted to PRME CEE activities of 2019-2020 reporting, news from our schools and universities. The session was led by Gabor Harangozo, PhD, with the title "Experience and characteristics of attitudes toward PRME affairs in schools with a different background. During the last session were discussed the next steps of PRME CEE for the upcoming year. As a special guest, Prof. Mathias Schuetz (ZHAW, Switzerland) provided a lecture on "Ethics in COVID time."

\subsection{Past activities}

\subsubsection{Sixth PRME CEE Regional Meeting, Corvinus Business School (Budapest, Hungary), 2019}

Between 30 and 31 May 2019, 19 colleagues from 11 business schools worked together for two days at Corvinus Business School to join efforts 
for promoting ecological and social sustainability in and of higher education. The Central and Eastern European Chapter of the UN-based PRME (Principles for Responsible Management Education) shared its good practices, learned about Corvinus Science Shop, and elaborated on six future projects. Thanks to the cooperation Prague University of Economics (VSE), University of Ljubljana School of Economics and Business, Warsaw School of Economics (SGH), Lomonosov Moscow State University, Russian Presidential Academy of National Economy and Public Administration (RANEPA), Bled School of Management, CEEMAN, Cracow University of Economics, Lviv Business School, University of Zagreb and Budapest Business School (BGE).

\subsubsection{Fifth PRME CEE Regional Meeting, University of Ljubljana School of Economics and Business (Slovenia), 2018}

The fifth PRME Chapter CEE meeting took place at the University of Ljubljana School of Economics and Business, Slovenia, from 5 to 8 September 2018. The meeting title: Creatively educating socially responsible citizens of the world, with the guest speakers: full professor Sandra Penger, PhD, associate professor Jože Rovan, PhD, assistant professor Darija Aleksić, PhD, assistant professor Judita Peterlin, PhD, Healthy lifestyle promotor Nataša Mulec, MSc, and student and entrepreneur Andraž Flis. The event has been managed and coordinated by assistant professor Judita Peterlin, $\mathrm{PhD}$, and Ms. Klavdija Besednjak (University of Ljubljana School of Economics and Business).

\subsubsection{Fourth PRME CEE Regional Meeting, Prague University of Economics (Czech Republic), 2017}

The fourth PRME Chapter CEE meeting took place at the University of Economics, Prague, the Czech Republic from 30 to 31 August 2017, and was organized within the framework of ERASMUS + Training. Meeting title: Responsibility and Ethics in Management Education for PRME CEE. Guest speaker: Prof. Dr. Mathias Schüz for business ethics from ZHAW University, Zurich. The event has been managed and coordinated by Dušan Kučera, PhD, MBA (University of Economics, Prague, ISBM institute). 


\subsubsection{Third PRME CEE Regional Meeting, RANEPA (Moscow, Russia), 2017}

The Third PRME Chapter CEE meeting takes place in Moscow, Russia on 13 January 2017 within the frames of the Gaidar Forum (http:// en.gaidarforum.ru/), and is hosted by The Russian Presidential Academy of National Economy and Public Administration (RANEPA) (http:// www.ranepa.ru/eng/). The FELU was presented by the Alumni President Mr. Janez Škrabec.

\subsubsection{Second PRME CEE Regional Meeting (Tallinn, Estonia), 2016}

The 2nd PRME Chapter CEE Meeting took place in Tallinn, within the frames of the 24th CEEMAN Annual Conference on 28 September. The main focus was on the future steps of the Chapter as well as discussing the topic of Boosting Social Entrepreneurship through Management Education. Close to 50 participants from 16 countries joined the meeting.

\subsubsection{First PRME CEE regional meeting, RISEBA (Riga, Latvia), 2016}

The chapter held its 1st PRME Regional Meeting CEE on 18-19 April 2016 at RISEBA University of Applied Sciences in Latvia. During this meeting, 56 delegates from 19 PRME signatory business and management schools across Central and Eastern Europe came together to agree on a Constitution and Steering Committee and to discuss ideas on the roles, activities, and events for the new PRME Chapter.

\subsection{Future aspirations of Chapter in the Decade of Action}

The future aspirations are to grow the network of PRME signatories from CEE countries. The very important goal the PRME CEE Chapter sets is to grow the PRME signatories network in the region. It is to be done in two ways. First is to set up local, national chapters and to attract nonsignatories to become the PRME members. 
Second is to reach educational institutions in CEE countries where there are no PRME signatories. The idea is to present PRME concepts and ideas to academics from leading universities, nonsignatories. There will be at least one PRME signatory in every of the CEE Countries.

There will be developed manuals for education on sustainability and CSR in relation to PRME six principles and SDGs. The PRME CEE Chapter collects experiences on providing courses on that issues and improves the manuals and ways of teaching.

There will be conducted research projects on implementation of PRME six principles in CEE educational institutions as well as the implementation of the principles to life of universities and schools.

\section{References}

Allen, S., Cunliffe, A.L. and Easterby-Smith, M. (2019) 'Understanding sustainability through lens of econcentric radical - reflexivity: Implications for management education', Journal for Business Ethics, Vol.154, Iss.3, DOI: 10.1007/s10551-016-3420-3

Andersen, M. and Larsen, T.S. (2009) 'Corporate social responsibility in global supply chains, Supply Chain Management', An International Journal, Vol.14, Iss.2, pp.75-86.

Atriach, T., Lee, D., Nelson, D. and Walker, J. (2010) 'The determinants of corporate sustainability performance', Accounting Q Finance, Vol.50, Iss.1, DOI: https://doi.org/10.1111/j.1467-629X.2009.00315.x

Clemens, B. and Bakstran, L. (2010) 'A framework of theoretical lenses and strategic purposes to describe the relationship among firm environmental strategy, financial performance and environmental performance', Management Research Review, Vol.33, Iss.4, pp.393-405, DOI: http:// dx.doi.org/10.1108/01409171011030480

Cordasco, P. (2012) 'Consumers continue to prioritize social responsibility across business sectors', Despite Recession. http://www.burson-marsteller. com/newsroom/lists/Press Releases (Accessed 20 September 2020).

Cuerel Burbano, V. and Hawn, O. (2018) 'National culture and corporate sustainability', Academy of Management Annual Meeting Proceedings, Vol.2018, Iss.1. DOI:10.5465/AMBPP.2018.12471abstract

Du, S., Bhattacharya, C.B. and Sen, S. (2010) 'Maximizing business returns to corporate social responsibility (CSR)', The Role of CSR Communication, Corporate Social Responsibility, March, Vol. 12, Iss.1, pp.8-19. 
Fijałkowska, J., Zyznarska-Dworczak, B. and Garsztka, P. (2017) 'The relation between the CSR and the accounting information system data in Central and Eastern European countries: The evidence of the polish financial institutions', Journal of Accounting and Management Information Systems, Vol.16, Iss.16, pp. 490-521.

Gupta, M. (2012) 'Corporate social responsibility in the apparel industry: An exploration of Indian consumer's perceptions and expectations', Journal of Fashion Marketing and Management, Vol.16, Iss.2, pp.216-233.

Haertle, J. and Miura, S. (2014) 'Seven years of development: United Nationssupported principles for responsible management education', SAM Advanced Management Journal, Vol.79, Iss.4, Autumn.

Haski-Leventhal, D. (2014) 'MBA student values, attitudes, and behaviors: A cross-cultural comparison of PRME signatory schools', SAM Advanced Management Journal, Vol.79, Iss.4, Autumn,

Hillon, Y.T. (2017) 'Heroic narratives of intentional non-compliance with PRME', Society and Business Review, Vol.12, Iss.3, pp.256-273, DOI: https:// doi.org/10.1108/SBR-10-2016-0054

Hogdal, C., Rasche, A., Schoeneborn, D. and Scotti, L. (2019) 'Exploring students perceptions of the hidden curriculum in responsible management education', Journal of Business Ethics, June, DOI: https://doi.org/10.1007/ s10551-019-04221-9 9

Laan, G.V, Ees van, H. and Wiitteloostuijn van, A. (2008) 'Corporate social and financial performance: An extended stakeholder theory, and empirical test with accounting measures', Journal of Business Ethics, Vol.79, pp.299-310, DOI: http://dx.doi.org/10.1007/s10551-007-9398-o

Lee, D.D., Faff, R.W. and Smith, K.L. (2009) 'Revisiting the vexing question: Does superior corporate social performance lead to improve financial performance?' Australian Journal of Management, Vol.34, pp.1-49, DOI: http://dx.doi.org/10.1177/031289620903400103

McDonagh, J., Olafsdottir, R., Weir, L., Mahon, M., Farrel, M. and Conway, T. (2020) 'Nothing is sustainable the way it is - reflections on local sustainability perceptions and interpretations', (in:) McDonagh, J. and Tuulentie, S. (eds.), Sharing Knowledge for Land Use Management. Edward Elgar Publishing, Cheltenham, pp.100-115.

Menguc, B., Auh, S. and Ozanne, L. (2010) 'The interactive effect of internal and external factors on a proactive environmental strategy and its influence on a firm's performance,' Journal of Business Ethics, Vol.94, pp.279-298, DOI: http://dx.doi.org/10.1007/s10551-009-0264-0 
Mittal, R.K., Sinha, N. and Singh, A. (2008) 'An analysis of linkage between economic value-added and corporate social responsibility', Management Decisions, Vol.46, Iss.9, pp.1437-1443, DOI: http://dx.doi. org/10.1108/00251740810912037

Mrówka, R. and Pindelski, M. (2012) 'The influence of environmental changes in companies' approach to CSR', (w:) Kaczmarek, J. and Rojek, T. (red.), Dilemmas of the Contemporary Economy Facing Global Changes. Cracov University of Economics, Cracow, pp. 511-524, http://web.sgh.waw. $\mathrm{pl}$ / rmrowka/Publikacje/Mrowka, \%20Pindelski\%20-\%20CSR.pdf

Panda, K., Kumar, A., Jakhar, S., Luthra, S., Garza - Reyes, J.A., Kazancoglu, I. and Nayak, S.S. (2020) 'Social and environmental sustainability model on consumers' altruism, green purchase intention, green brand loyalty and evangelism', Journal of Cleaner Production, Vol.243, January, DOI: https:// doi.org/10.1016/j.jclepro.2019.118575

Pindelski, M. (2012) 'Ethics, CSR and CSV in the strategic orientations', Przeglad Organizacji, Vol.2, pp.6-10.

Porter, M. and Kramer, M. (2006) 'The link between competitive advantage and corporate social responsibility', Harvard Business Review, December, pp. 1-14.

Quairel-Lanoizelée, F. (2011) 'Are competition and corporate social responsibility compatible? The myth of sustainable competitive advantage', Society and Business Review, 6(1), 77-98.

Rahim, R.A., Jalaluddin, F.W. and Tajuddin, K. (2011) 'Consumers behaviour towards CSR in Malaysia', Asian Academy of Management Journal, Vol.16, Iss.1, pp.119-139.

Reficco, E., Jaen, M.H. and Trujillo, C. (2019) 'Beyond knowledge: A study of Latin American business schools' efforts to deliver value-based education', Journal of Business Ethics, Vol.156, Iss.14, pp.857-874.

Remisova, A. and Lasakova, A. (2014) 'CSR-related managerial decision-making preferences in the CEE Region (Result of the Globe Student Research)', Social and Behavioral Sciences, Vol. 110, January, pp. 913-922.

Schmidt, P., Bamberg, S., Davidov, E., Herrmann, J. and Schwartz, S.H. (2007) 'Die Messung von Werten mit dem "portraits value questionnaire" (Measuring values with the portraits value questionnaire)', Zeitschrift für Sozialpsychologie, Vol.38, pp.261-275, DOI: https://doi. org/10.1024/0044-3514.38.4.261 
Schwartz, S.H., Melech, G., Lehrnami, A., Burgess, S., Harris, M. and Owens, V. (2001) 'Extending the cross-cultural validity of the theory of basic human values with a different method of measurement', Journal of CrossCultural Psychology, Vol.32, pp.519-542.

Silvius, A.J.G. and Schipper, R.P.J. (2018) 'Exploring responsible project management education', Education Sciences, Vol.9, Iss.1, DOI: 10.3390/ educscigorooo2

Stanisavljevic, M. (2017) 'Does customer loyalty depend on corporate social responsibility', Our Economy, Vol.63, Iss.1, pp.38-46, DOI: https://doi. org/10.1515/ngoe-2017-0004 